Journal of Bangladesh Academy of Sciences, Vol. 38, No. 2, 167-175, 2014

\title{
CAECAL-INOCULATION OF ENTAMOEBA HISTOLYTICA IN THE IMMUNODEPRESSED SWISS ALBINO MICE TREATED WITH CYCLOPHOSPHAMIDE
}

\author{
RIFAT FARUQUI, HAMIDA KHANUM* ${ }^{*}$, RASHIDUL HAQ ${ }^{1}$, A.S.M. HAMIDUR \\ RAHMAN $^{1}$ AND NASIRUL ISLAM ${ }^{1}$
}

Department of Zoology, University of Dhaka, Dhaka-1000, Bangladesh

\begin{abstract}
A total of 72 mice were used for an experimental model of intestinal amoebiasis developed in the Swiss albino mice dividing into three groups, experimental immunocompetent mice group (Group-A), experimental immunodepressed mice group (Group-B) and control group (Group-C). The inoculum ( $10^{6}$ cells of Entamoeba histolytica $/ 0.2 \mathrm{ml}$ of medium) was used to inoculate into the caecum of the experimental groups of mice in the ICDDR,B laboratory, Dhaka. The mice were sacrificed at 5, 10, 15, 20, 25 and $30^{\text {th }}$ days after inoculation for observation of caecal lesions and gross pathologic changes and histopathological analysis. The animals in the experimental two groups and control did not develop any caecal amoebiasis. The culture results of the stool of the mice which were inoculated with the inoculum of E. histolytica were found to be positive on the first 10 days after post caecal inoculation. After 10 days, the culture results were negative and the antiamoebic antibody levels of all animals were also found negative.
\end{abstract}

Key words: Caecal inoculation, Entamoeba histolytica, Swiss albino mice

\section{INTRODUCTION}

Amoebic dysentery and liver abscesses are life threatening infections which occur specially in the populations of developing countries in Asia, Africa and Latin America. Majorities of infected individuals (90\%) are asymptomatic carrier of the parasites. Symptomatic infections varies in severity from mild diarrhea to potentially life threatening abscess. World-wide morbidity and mortality due to amoebiasis is difficult to estimate. An estimate suggests that approximately 500 million people are infected worldwide with this parasite and causing about 110,000 deaths per year (Walsh 1986, Neal 1983, Robinson 1968, Bhopale et al. 1995).

Infection of E. histolytica is caused by ingestion of the cyst of the parasite. The disease results when the trophozoites invade the intestinal epithelium. Mucosal invasion by amoebas with the aid of proteolytic enzymes occurs through the crypts of Lieberkuhn,

\footnotetext{
* Corresponding author: <hamida_khanum@yahoo.com>.

${ }^{1}$ International Centre for Diarrhoeal Disease Research, Bangladesh (ICDDR,B), Mohakhali, Dhaka-1212, Bangladesh.
} 
forming discrete ulcers with a pinhead-sized centre and raised edges from which mucus necrotic cells and amoebas may disseminate extra-intestinally producing abscesses in a variety of organs, largely in livers (Perez-Tamayo 1986, Kondo 1939, Bertha et al. 1992).

In the past, different laboratory animals have been used for experimental establishment of amoebiasis in animal systems. The experimental intestinal infections with E. histolytica have been induced in a variety of animals, including dogs (Loesch 1875), cats (Kartulis 1891), rats (Neal and Harris 1975) rabbits (Tobie 1949), and guineapigs (Diamond et al. 1978). Some attempts to produce hepatic amoebiasis have been successful by intrahepatic, intramesenteric and intraportal inoculation of trophozoite of $E$. histolytica in dogs (Kondo 1939), kittens (Cleveland and Sanders 1930), rats (Reinertson and Thompson 1951) and guinea-pigs (Maegraith and Harinasuta 1953, Gill et al. 1983), hamsters (Jarumilinta and Maegraith 1962, Lush-Bough et al. 1978) and rabbits (GilBarbosa et al. 1972). Although a variety of laboratory animals have been used, the mouse whose genetic and immunology is well-known has been seldom used. A very few investigators have attempted to establish caecal amoebiasis in mice (Neal and Harris 1975, Gold and Kagan 1978) but the results were inconclusive.

An experimental model of intestinal amoebiasis was developed in the Swiss albino mouse. This subject was selected for its cheapness, easy handling and known genetical and immunological information. Previously a study was done on the normal mice (immunocompetent mice) and there was no amoebiasis could be established (Faruqui $e t$ al. 2004). Another experimental model was needed to establish amoebiasis. For this reason an immunodepressed mouse model was developed by the treatment of cyclophosphamide. By the present experiment it was aimed to produce amoebiasis in the animal system for better understanding of the patho-physiological mechanism of the disease and to acquire knowledge on the pathogenesis of $E$. histolytica in animal system and testing the effectiveness of drugs against infection.

\section{MATERIALS AND METHODS}

In the present investigation three to six-week-old Swiss albino mice of both sexes weighing approximately $20-30 \mathrm{~g}$ were chosen. These mice were supplied by the Animal

Resources Branch (ARB), of ICDDR,B, Mohakhali, Dhaka. Although there was no evidence of naturally occurring intestinal amoeba in mice, they were treated with antiamoebic drug metronidazole $(15-20 \mathrm{mg} / \mathrm{kg}$ body weight) before the inoculation. The stools were checked in treated animals for evidence of amoebic cyst. A total of 72 Swiss albino mice were selected for this study. They were divided into three groups: an experimental immunocompetent group (Group-A), an experimental immunodepressed (Group-B) and control group (Group-C). The animals were injected into caecum with the inoculums. 
An experimental immunocompetent mice group (Group-A): In this group, 24 mice were selected among them 12 were male and remaining 12 were female. These mice were not treated with cyclophosphamide.

An experimental immunodepressed mice group (Group-B): A total of 24 mice were selected, among them 12 were male and remaining 12 were female. These mice were treated with cyclophosphamide to develop immunodepressed mice group. Immunodepression was induced in the way by giving cyclophosphamide intraperitoneally. Cyclophosphamide is an alkylating agent which exerts its damaging effect on cells during mitosis and is a potent B-cell suppressant (Turk 1973). Immunodepression commenced approximately 48 hours before inoculation. In the mice of group-B, cyclophosphamide (cp) at a total dose of $300 \mathrm{mg}$ per $\mathrm{kg}$ body-weight was given intraperitoneally (IP) in two divided doses on two consecutive days.

Control group (Group-C): The control group of mice were similarly treated except that they were injected only with Robinson's medium.

Preparation of the inoculums: To prepare inoculum, trophozoites of E. histolytica of human origin were used. The inoculum was kept at $37^{\circ} \mathrm{C}$ and was injected within an hour of its preparation. The inocula were prepared from long phage trophozoites. The trophozoites and the cysts were obtained from dysenteric or diarrheal stools which were collected from an urban slum of the study area in Mirpur of Dhaka city. The trophozoites and the cysts were detected under direct microscopic stool examinations. After the detection, the stool samples were inoculated into Robinson's medium (Robinson 1968) for the cultivation and isolation of E. histolytica. Then, ELISA technique (Haque et al. 1995) was used to detect amoebic antigen in the culture sediments of the stool samples.

Infective dose: E. histolytica was harvested after a 48 hours of growth period. From pooled cultures of several bottles, the trophozoites were concentrated by centrifugation for two minutes at 12000 r.p.m. The sediments containing the torphozoites were then transferred in eppendorf tubes with medium and then counted with the aid of a haemocytometer. The number/volume adjusted to contain $10^{6}$ cells in $0.2 \mathrm{ml}$ medium. Each animal was inoculated intra-caecally with the inoculum $\left(10^{6}\right.$ cells $/ 0.2 \mathrm{ml}$ medium $)$.

Experimental procedure: Before surgery, the mice were anaesthatized with ether in a glass jar. The optimal anaesthesia was obtained when the mouse started long uniform breathing showing no sensation in the nictitating membrane of the eyes.

Operative technique: The intra-caecal inoculations were performed 10 days after the treatment with metronidazole. An aseptic technique was followed throughout the procedure. The animals fasted for $48 \mathrm{~h}$ before the anesthesia to decrease the fecal content in the large intestine. The animals were anaesthetized by applying ether inhalation. A small portion of abdomen was shaved with blade, cleaned and then cut opened by a 
longitudinal midline incision through the skin and the peritoneum. The caecum was identified and a $0.2 \mathrm{ml}$ of the inoculums was slowly injected at the apex of the caecum using a 27 gauge needle fitted in a tuberculin syringe. After withdrawing the needle, a wet swab soaked in normal saline was placed over the site of puncture for a few seconds to check possible leakage outside the caecum. After the inoculation, the incision was closed by sewing with thread. The control mice were inoculated only with the medium. None of the animals died during the experimental procedure. After the operation, the animals were kept in individual cages for observation.

Post inocular observation: The experimental animals were checked daily for any evidence of diarrhoea. Their stools were collected daily for cultivation of amoebae and were weighed every day. Surviving animals were killed by giving heavy doses of ether at $5,10,15$, 20, 25 and 30th days after the inoculation, and their autopsies were performed immediately. During the autopsy, the abdomens were opened and the cardiac bloods were collected from the heart of the mice using 27 gauge needles fitted with the syringes to detect the antiantibodies developed against E. histolytica. The entire gastrointestinal tracts were dissected out in Petri dishes with normal saline. The tracts were longitudinally dissected and examined for the development of any ulcers. The smears of the suspected areas were examined directly for the presence of any E. histolytica. The smears also cultured in 24-hour-preconditioned Robinson medium. The cultures were examined every 24 hours for three days.

Collection of tissue: The caecum of the treated mice were dissected out and opened longitudinally to examine the mucosal surface and was fixed in $10 \%$ normal saline. Some of its tissues were processed for $5 \mu \mathrm{m}$ thick histological slides and they were stained with hematoxylin and eosin.

Antibody detection: In each cases, the blood samples were collected from the living mice. The serum was separated from the blood by clotting and then by centrifuging. The serum samples were preserved at $-20^{\circ} \mathrm{C}$. The sera were used for ELISA for the detection of anti-amoebic antibodies.

\section{RESULTS AND DISCUSSIONS}

Seventy two Swiss albino mice were selected for this experiment. Among them 48 were induced with the inoculum of E. histolytica. No animals in this experiment produced any intestinal amoebiasis (Table 1).

Findings of clinical pathology: In most of the mice no faecal changes were observed, even when cyst or trophozoites of E. histolytica were present in faeces. Diarrhoea did not appear in those animals. Also, no lesions were found in the gastro-intesinal tracts specially in the caeca, colon or rectums. The caeca were not changed and their walls were not thickened. The caecal contents were not watery, mucous filled or bloody. 
Table 1. 
Findings of histopathology: The experiments were carried out on immuno-competent and immuno-depressed mice group. They were inoculated intra-caecally with the inoculum $\left(10^{6}\right.$ cells $/ 0.2 \mathrm{ml}$ medium) of E. histolytica, whereas the control group was inoculated intra-caecally with only normal saline. During the observation period, the culture results of the stool of all the mice were positive at first tenth days after inoculation. So, the intestinal samples were collected from those mice for histological study. To accomplish this, autopsies were performed at 5, 10, 15, 20, 25 and $30^{\text {th }}$ days after the inoculation. No macroscopic lesions were visible. The autopsies were also performed in a control group of mice at the same days after the inoculation.
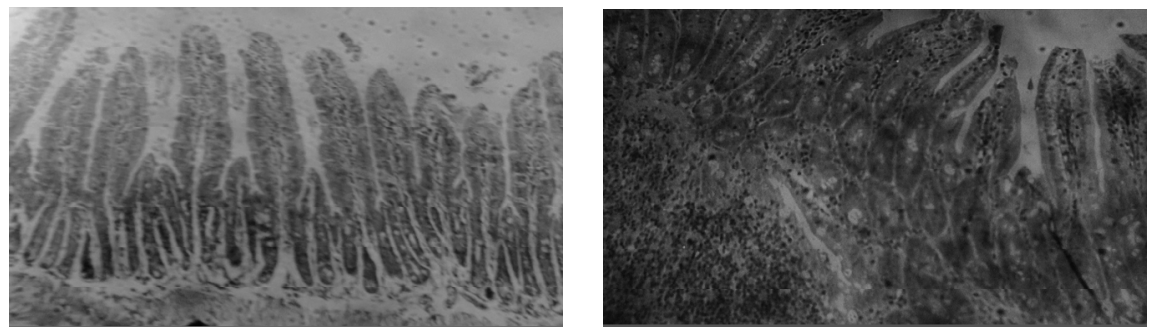

Fig. 1. (Left) A section through villi of mucosa layer of the ileum from intra-caecally infected immunocompetent mouse; (Right) A section of ileum from cyclophosphamide-treated, intracaecally inoculated mouse showing stunted villi of ileum may be due to cyclophosphamide treatment.

The successful production of intestinal E. histolytica infection in laboratory animals is a vital problem in chemotherapeutic research on amoebiasis (Bhopale et al. 1995). Although, small population of laboratory animals are not the natural hosts of $E$. histolytica, numerous reports indicate that there is a fairly good correlation between antiamoebic drug responses in the natural and experimental hosts (Neal 1983).
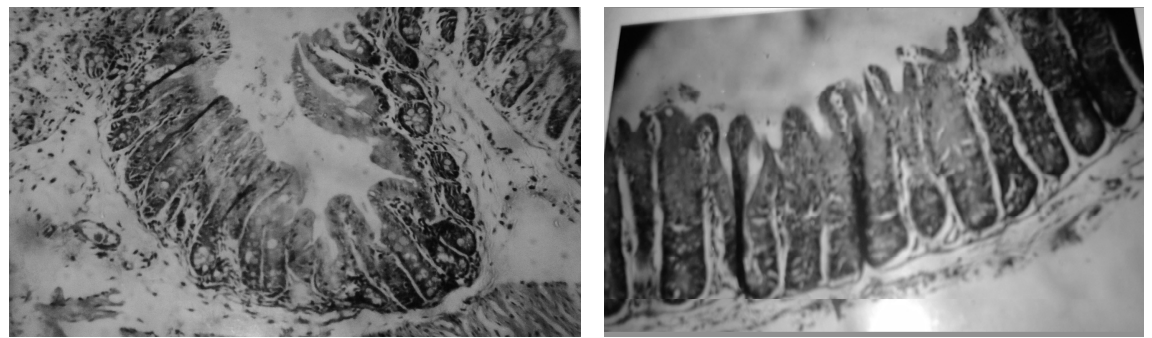

Fig. 2. (Left) A section through villi of mucosa layer of the caecum from intra-caecally infected immunocompetent mouse; (Right) A section of caecum from cyclophosphamide-treated, intra-caecally inoculated mouse showing stunted villi of caecum may be due to cyclophosphamide treatment.

Although, attempts have also been made to establish caecal amoebiasis in albino mouse (Neal and Harris 1975, Gold and Kagan 1978), the variability in infection rate and 
development of lesions usually make this model unsuitable for drug screening. However, Ray et al. (1982) claimed to have produced uniform infection in mice by purging the animals with magnesium sulphate prior to the infection, and used this model for screening potential amoebicides.

Table 2. ELISA of direct stool and blood samples of Swiss albino mice and histopahtological results of the intestinal portion.

\begin{tabular}{|c|c|c|c|c|c|c|}
\hline $\begin{array}{l}\text { Group of } \\
\text { mice }\end{array}$ & $\begin{array}{l}\text { No. of } \\
\text { mice }\end{array}$ & Sex & $\begin{array}{l}\text { Results of Eh- } \\
\text { ELISA } \\
\text { test of culture of } \\
\text { stool samples }\end{array}$ & $\begin{array}{l}\text { Results of anti-lectin- } \\
\text { antibody ELISA } \\
\text { test of serum of blood } \\
\text { samples. }\end{array}$ & $\begin{array}{l}\text { Results of anti- } \\
\text { CRD of lectin } \\
\text { antibody } \\
\text { response }\end{array}$ & $\begin{array}{c}\text { Results of } \\
\text { histopathology of } \\
\text { the villi of intestinal } \\
\text { caecum of mice }\end{array}$ \\
\hline \multirow[t]{2}{*}{ Group-A } & 12 & Male & $+\mathrm{ve}$ & $-\mathrm{ve}$ & $-\mathrm{ve}$ & $\begin{array}{l}\text { Remain unchanged } \\
\text { (Normal) }\end{array}$ \\
\hline & 12 & Female & $+\mathrm{ve}$ & $-\mathrm{ve}$ & $-\mathrm{ve}$ &, \\
\hline \multirow[t]{2}{*}{ Group-B } & 12 & Male & $+\mathrm{ve}$ & $-\mathrm{ve}$ & $-\mathrm{ve}$ & Became stunted \\
\hline & 12 & Female & $+\mathrm{ve}$ & $-\mathrm{ve}$ & - ve & ", \\
\hline \multirow[t]{2}{*}{ Group-C } & 12 & Male & $-\mathrm{ve}$ & $-\mathrm{ve}$ & - ve & Normal \\
\hline & 12 & female & $-\mathrm{ve}$ & $-\mathrm{ve}$ & $-\mathrm{ve}$ & , \\
\hline
\end{tabular}

In this study, monoxenic E. histolytica trophozoites were inoculated intra-caecally in the Swiss albino mice. Preliminary experiments showed that monoxenic E. histolytica trophozoites inoculated directly into the caecum of mice did not produce intestinal amoebiasis. Only monoxenically grown trophozoites, which had been previously conditioned by two or three passages into hamster's liver produced caecal amoebiasis in mice (Prabir et al. 1994). In this model, this type of trophozoites were not used. Therefore, no lesions were found in the intestine of mice. The results of this experiment indicate that the amoebae could not settle in the caecum of the mice probably for not getting considerable times for infection. So from this type of observation we can easily understand that virulent strain is very important to produce amoebiasis.

In a previous study, the mice were inoculated with the low $\left(10^{3}\right.$ cells $/ 0.2 \mathrm{ml}$ of medium) and moderate $\left(10^{5}\right.$ cells $/ 0.2 \mathrm{ml}$ of medium) doses of inoculum (Faruqui et al. 2004), no cysts or trophozoites were found after microscopic stool examinations. Also no trophozoites were found in the culture of stool samples of those mice. Whereas, trophozoites were found in the culture of stool samples, a high dose of inoculums of trophozoites was used to colonize E. histolytica in the caecum of mice $\left(10^{6}\right.$ cells $/ 0.2 \mathrm{ml}$ of medium).

During the present observation period, no diarrhoea was observed in any experimental mice. The results of microscopy and observation of stool were also negative, whereas culture results were positive. The results of the antigen detection test ELISA were positive. The serological test of anit-lectin antibodies and anti-lectin CRD antibodies were negative. 
The intestinal samples were collected from those mice of two experimental groups for histological study. To accomplish that autopsies were performed and no macroscopic lesions were visible after opening the abdomen. The caecum and other parts of the intestine appeared normal when examined under dissecting microscope. Microscopic examination revealed that there was no evidence of infection. After histological analysis the villi of the caecum and other parts of the intestine remained unchanged (normal) and no lesion appeared. No microscopic lesions were visible on mucosa layer of the ileum, caecum and colon. Only on the immunodepressed group of mice (Group-B) the villi of the intestinal parts became stunted due to cyclophosphamide treatment.

The strain of E. histolytica which was tested in mouse model could not produce evidence of diseases both clinically and histogically. The possible reasons may be either the strain of E. histolytica which was obtained from human source was not susceptible to cause infection in mice or the immune system of the adult Swiss albino mouse was competent enough to withstand the amoebic infection.

\section{CONCLUSION}

The present investigation proved that the laboratory mice are not infected with $E$. histolytica. So, it may be suggested that, these mice are not suitable for the experimental model of caecal inoculation. This experiment was on trial basis. Further study may be carried out on malnourished mouse or another animal models (Rat, rabbit or guinea-pig).

\section{ACKNOWLEDGEMENTS}

The authors are grateful to the authority of Animal Resources Branch (ARB) of ICDDR,B, Mohakhali, Dhaka for providing the laboratory facilities and other supports to run the research work successfully.

\section{REFERENCES}

Bertha, B.V., I.M. Emma, R. Fernando and X. Cecilia. 1992. Local and systemic antibody response in Balb/c mice immunized with E. histolytica trophozoites. Arch. Med. Res. 23: 69-72.

Bhopale, K.K., K.S. Pradhan, K.B. Masani and C.K. Kaul. 1995. A comparative study of experimental caecal amoebiasis and the evaluation of amoebicides. Ann. Trop. Med. and Para. 3: 253-259.

Cleveland, L. R. and E.P. Sanders. 1930. The production of bacteria-free amoebic abscesses in the liver of cats and observations on the amoebae in various media with and without bacteria. Science 72: 149.

Diamond, L.S., M. Tanimoto-Weki and A. Martinez-Palomo. 1978. Production of cecal lesions in newborn guinea-pigs with axenically cultivated E. histolytica. Arch. Invest. Med. (Mex). 9: 223-228.

Faruqui, R., H. Khanum, R. Haq, A. Rahman and S.M. Hamidur. 2004. Experiment on caecal inoculation of Entamoeba histolytica in the Swiss albino mice. Bangladesh J. Zool. 32(2): 113-120. 
Gill, N.J., N.K. Ganguly, R.C. Mahajan, S.R. Bushnurmath and J.B. Dilwari, 1983. Model of amoebic liver abscess in cholesterol fed guinea-pigs through intracaecal infection route. Ind. J. Med. Res. 78: 489-496.

Gil-Barbosa, G.M., A.F. De ShorDe, M. La Torrie, and J. Villegas-Gonzalez. 1972. Sequence of amoebic hepatic lesions in rabbit. Arch. Invest. Med. 5:(suppl. 2) 349-354.

Gold, D. and Kagan, I.G. 1978. Susceptibility of various strains of mice to Entamoeba histolytica. J. Para. 64: 937-938.

Haque, R., L.M. Neville, P. Hahn and W.A. Petri Jr. 1995. Rapid diagnosis of Entamoeba infection by using Entamoeba histolytica stool antigen detection kits. J. Clin. Microbiol. 33(10): 2558-2561.

Jarumilinta, R. and B.G. Maegraith. 1962. The induction of amoebic liver abscesses in hamsters by intra-peritoneal inoculation of trophozoites of Entamoeba histolytica. Ann. Trop. Med. Para. 56: $248-254$.

Kartulis, S. 1891. Einiges uber die Pathogens der Dysenterieamoben. Zbl. Bakt. 40: 130.

Kondo, H. 1939. Investigations of amoebic dysentery. XXI: Experimental studies of amoebic liver abscesses in dogs. [In Japanese; English Summery.] J. Orient. Med. 31: 2.

Loesch, F. 1875. Massenhafle Entwickelung von Amoben imm Dickdarm Virchows. Arch. 65:196.

Lushbaugh, W.B., A.B. Kairalla, C.B. Loadholt, and E.F. Pittman. 1978. Effects of hamster liver passage on the virulence of axenically cultivated Entamoeba histolytica. Am. J. Trop. Med. Hyg. 27: 248.

Maegraith, B.G. and C. Harinasuta. 1953. Experimental amoebic infection of liver in guinea-pigs. 1infection via mesenteric vein an via portal vein. Ann. of Trop. Med. and Para. 48: 421-433.

Neal, R.A. and W.G. Harris. 1975. Attempts to infect inbred strains of rats and mice with $E$. histolytica. Trans. Roy. Soc. Trop. Med. Hyg. 69: 429-43.

Neal, R.A. 1983. Experimental amoebiasis and the development of anti-amoebic compounds. Para. 86: $175-191$.

Perez-Tamayo, R. 1986. Pathology of amoebiasis. Martinez-palomo A. Ed. Amoebiasis. Amsterdam: Elsevier Biomedical: 45.

Prabir, K.G., R. Mancilla, and L. Ortiz. 1994. Intestinal Amoebiasis: Histopathologic features in experimentally infected mice. Arch. Med. Res. 25: 297-302.

Ray, D.K. J.S. Tendulkar, V.B. Shrivastava and K. Nagarajan. 1982. Comparative efficacy of metronidazole and another nitoimidazole. CG-10213-Go, in the caecal amoebiasis in albino mice (Mus musculus). J. Antimicro Chemo. 10: 355-357.

Reinertson, J.W. and P.E. Thompson. 1951. Experimental amoebic hepatitis in hamsters. Proc. Soc. Exp. Biol. Med. 76: 518-521.

Robinson, G.L. 1968. The laboratory diagnosis of human parasitic amoeba. Trans R. Soc. Trop. Med. Hyg. 62: 285.

Tobie, J.E. 1949. Experimental infection of the rabbit with Endamoeba histolytica. Ibid. 29: 859.

Turk, J.L. 1973. The use of cyclophosphamide in non-neoplastic disease-evidence for a preferential effect of cyclophosphamide on B cells. Proceedings Royal Soc. Medi. 66: 805-808.

Walsh, J.A. 1986. Problems in recognition and diagnosis of amebiasis: estimation of global magnitude of morbidity and mortality. Rev. Infect. Dis. 8: 228-238. 